\title{
GSK-3beta inhibitory effects of 6-gingerol and 6-shogaol help to the recovery of SHSY-5Y cells after amyloid beta1-42 oligomer or aggregate toxicity
}

\author{
Mukerrem Betul Yerer*, Mehmet Kaan Tiryaki and Eren Demirpolat \\ Department of Pharmacology, Faculty of Pharmacy, Erciyes University, Kayseri, Turkey
}

\begin{abstract}
.
BACKGROUND: GSK-3 $\beta$, has been shown to regulate APP cleavage resulting in the increased production of A $\beta$ and the inhibition of the GSK-3 $\beta$ reduced the amyloid beta induced neurotoxicity in several studies.

OBJECTIVE: This study was designed to investigate the GSK-3 $\beta$ inhibitory effects of 6-gingerol and 6-shogaol the major components of Zingiber officinale could be able to recover the SHSY-5Y cells from Amyloid beta 1-42 oligomer and aggregate toxicity.

METHODS: SHSY-5Y (ATCC; CRL-2266) cells were maintained in Dulbecco's modified eagle medium (DMEM, Gibco) containing $10 \%$ fetal calf serum, $100 \mathrm{U} / \mathrm{mL}$ penicillin, $50 \mu \mathrm{g} / \mathrm{mL}$ streptomycin, at $37^{\circ} \mathrm{C}$ and $5 \% \mathrm{CO} 2$ in a humidified incubator. Cells were transferred to sterile 96-well e-plates at $5 \times 10^{4}$ cells per well and followed real time for 78 hours via Xcelligence system. Ferulic acid was used as a positive control as a GSK-3 $\beta$ inhibitor at $4 \mu \mathrm{M}$ dose and 6-gingerol and 6-shogaol were applied to the cells at $0.01 \mu \mathrm{M}, 0.1 \mu \mathrm{M}, 1 \mu \mathrm{M}, 10 \mu \mathrm{M}, 100 \mu \mathrm{M}$ doses $/ 50 \mu \mathrm{L}$ with or without $\beta$-Amyloid $1-42$ oligomers or aggregates. GSK-3 $\beta$ activity was determined by Kinase-Glo assay.

RESULTS: Both the amyloid beta aggregates and the oligomers had cytotoxic effect on SHSY-5Y cells followed by the real time cell analyzer system. 6-gingerol and 6 shogaol inhibited the GSK-3 $\beta$ enzyme up to \% 20 levels in a dose dependent manner until $1 \mu \mathrm{M}$. However, parallel with the reduction of the inhibition for 6-shogaol over $1 \mu \mathrm{M}$, showed a toxicity itself on SHSY-5Y cells, whereas 6-gingerol did not show any cytotoxic effect at any doses applied.

CONCLUSIONS: 6-gingerol and 6-shogaol increased the cell viability followed in a real time manner after around 24 hours than the amyloid beta aggregate or oligomer toxicity as much as the ferulic acid could. Furthermore these effects supported the GSK-3 $\beta$ inhibitory effects of both compounds at low doses up to $1 \mu \mathrm{M}$. These results reveal that 6-gingerol and 6-shogaol the major components of Zingiber officinale help to recovery from amyloid beta toxicity which might further be investigated by clinical trials.
\end{abstract}

Keywords: GSK-3 $\beta$, Amyloid $\beta 1-42$ oligomer, Amyloid $\beta 1-42$ aggregate, 6-gingerol, 6-shogaol, ferulic acid

\section{Introduction}

Amyloid $\beta(A \beta)$ is a small self-aggregating peptide produced at low levels by normal brain metabolism and extensive amounts in Alzheimer patients' brain which was firstly identified by Glenner and Wong [1] in 1984. Hardy and Higgins were the first to drive the amyloid cascade hypothesis to science [2] and since then many studies have tried to reveal the relationship between the amyloid beta

\footnotetext{
*Corresponding author: Mukerrem Betul Yerer, PhD., Erciyes University, Faculty of Pharmacy, Department of Pharmacology, 38039 Kayseri, Turkey. Tel.: +90 352 4380486; Fax: +90 352 4379169; E-mail: eczbetul@yahoo.com.
} 
plaque formation and pathology of the disease [3-5]. A number of reports have dealt with assessment of the effects of peptide length on fibril formation or cytotoxicity [5, 6]. $\beta A 1-42$ is neurotrophic in its initially solubilized state but showed aggregation and neurotoxicity in cells in culture after $2-4$ day preincubation of the peptide [7]. The relationship between the tangles, plaques and the disease became more precious [8] and the century of the Alzheimer disease was well reviewed by Goedert et al. in 2006 [9]. Although there is a link between the disease and the mutations which firstly shown to be the reason [10], the pathology of the disease was further linked with oxidative stress [11], inflammation [12] and even diabetes [13] with several studies. Further studies shown the importance of protein kinases especially in the Wnt signalling which is important for the cell survival and the neurodegeneration $[14,15]$. GSK-3 $\beta$, has been shown to regulate APP cleavage resulting in the increased production of A $\beta[16$, 17]. Exposure of neurones to $A \beta$ increases GSK-3 $\beta$ activity through the inhibition of PI3-kinase signalling and blockade of either GSK-3 $\beta$ expression or activity prevents $A \beta$-induced neurodegeneration $[18,19]$. The inhibition of the GSK-3 $\beta$ reduced the amyloid beta induced neurotoxicity [20]. In our previous studies we have shown the GSK-3 $\beta$ inhibitory effects of 6-gingerol, 6-shogaol and curcumin [21] the major components of Zingiber officinale and Curcuma longa. Taking into account of these studies, in this study we aimed to investigate the neuroprotective effects of 6-gingerol and 6-shogaol on amyloid beta toxicity in SHSY-5Y cell line and its relation to their GSK-3 $\beta$ inhibitory activity.

\section{Materials and methods}

\subsection{Chemical and reagents}

Water was obtained using a Milli-Q system (Millipore, Billerica, MA, USA). Reagents were obtained in the highest purity available from Sigma-Aldrich, Germany, unless otherwise noted below.

\subsection{Following the real time effects of the compounds by Xcelligence (RTCA) system}

Cultured SHSY-5Y (ATCC; CRL-2266) human neuroblastoma cells were maintained in Dulbecco's modified eagle medium (DMEM, Gibco) containing $10 \%$ fetal calf serum, $100 \mathrm{U} / \mathrm{mL}$ penicillin, $100 \mu \mathrm{g} / \mathrm{mL}$ streptomycin, at $37^{\circ} \mathrm{C}$ and $5 \% \mathrm{CO}_{2}$ in a humidified incubator. The cells were passaged at least three times before use. Cells were transferred to sterile 96 -well e-plates at $5 \times 10^{4}$ cells per well and monitored for 78 hours. Ferulic acid was used as a positive control as a GSK-3 $\beta$ inhibitor at $4 \mu \mathrm{M}$ dose and 6-gingerol and 6-shogaol were applied to the cells at $0.01 \mu \mathrm{M}, 0.1 \mu \mathrm{M}, 1 \mu \mathrm{M}, 10 \mu \mathrm{M}$, $100 \mu \mathrm{M}$ doses $/ 50 \mu \mathrm{L}$ with or without $\beta$-Amyloid 1-42 (Catalog No. Anaspec. 20276) oligomers or aggregates.

\subsection{Preparation of the $\beta$-Amyloid 1-42 oligomers and aggregates}

$\beta$-Amyloid 1-42 fraction peptide was prepared according to the datasheet of the manufacturer, briefly $1 \mathrm{mg}$ peptide dissolved in PBS containing $\% 1 \mathrm{NH}_{4} \mathrm{OH}$ and used immediately after the preparation for monitoring the effects of oligomers. Amyloid beta aggregates were prepared from the oligomers by incubating the oligomers for $72 \mathrm{~h}$ at $37^{\circ} \mathrm{C}$ as described by Benseny et al. [22]. The modifications of the method were applied by taking the details given by other in vitro studies into account $[23,24] .22 \mu \mathrm{M}$ of $\mathrm{A} \beta$ solution was prepared in DMEM medium containing $0.5 \%$ (v/v) FBS and $2 \%$ penicillin/streptomycin. $50 \mu \mathrm{L}$ aliquots of the $A \beta$ solution were added to the wells to yield a final $A \beta$ 
concentration of $11 \mu \mathrm{M}$. The cells then were incubated in the presence of oligomer or aggregate until some degree of decline in cell viability was observed.

\subsection{GSK-3 $\beta$ activity}

Kinase-Glo assays were performed in assay buffer using black 96-well plates as described previously by Baki et al. [25] In a typical assay, $10 \mu \mathrm{l}(10 \mu \mathrm{M})$ of test compound (dissolved in dimethyl sulfoxide [DMSO] at $1 \mathrm{mM}$ concentration and diluted in advance in assay buffer to the desired concentration) and $10 \mu \mathrm{l}(20 \mathrm{ng})$ of enzyme were added to each well followed by $20 \mu \mathrm{l}$ of assay buffer containing $25 \mu \mathrm{M}$ substrate and $1 \mu \mathrm{M}$ ATP. The final DMSO concentration in the reaction mixture did not exceed $1 \%$. After a 30-min incubation at $30^{\circ} \mathrm{C}$ the enzymatic reaction was stopped with $40 \mu \mathrm{l}$ of Kinase-Glo reagent. Glow-type luminescence was recorded after $10 \mathrm{~min}$ using a HT Synergy (BioTek) multifunctional microplate reader. The activity is proportional to the difference of the total and consumed ATP. The inhibitory activities were calculated on the basis of maximal activities measured in the absence of inhibitor and given as \% inhibition compared to the positive control TDZD8 (T8325 Sigma, 4-Benzyl2-methyl-1,2,4-thiadiazolidine-3,5-dione).

\section{Results}

\subsection{The realtime effects of 6-gingerol, 6-shogaol and ferulic acid on cell proliferation without any amyloid beta toxicity}

6-gingerol has increased the cell indexes of the cells without any toxicity, however this elevation was not dose-dependent and statistically significant. The cell indexes were higher than the ferulic acid at the doses of $10 \mu \mathrm{M}, 100 \mu \mathrm{M}$ gingerol (Fig. 1).

6-shogaol had cytotoxic effect over $10 \mu \mathrm{M}$, and protective effect up to $1 \mu \mathrm{M}$ and this effect was better than the effect of ferulic acid (Fig. 2).

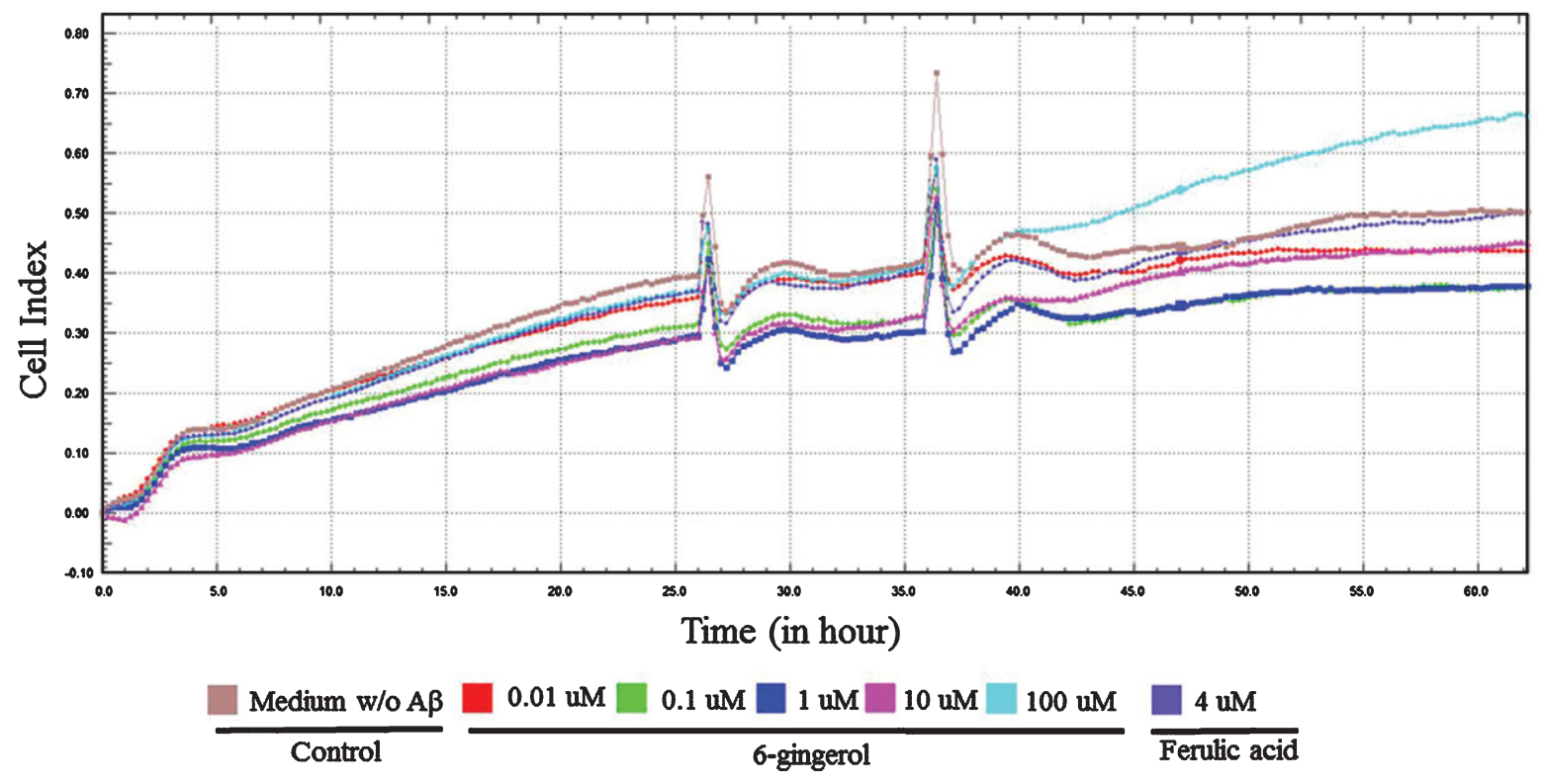

Fig. 1. The effect of 6-gingerol at $0.01 \mu \mathrm{M}, 0.1 \mu \mathrm{M}, 1 \mu \mathrm{M}, 10 \mu \mathrm{M}, 100 \mu \mathrm{M}$ doses $/ 50 \mu \mathrm{L}$ and ferulic acid. 


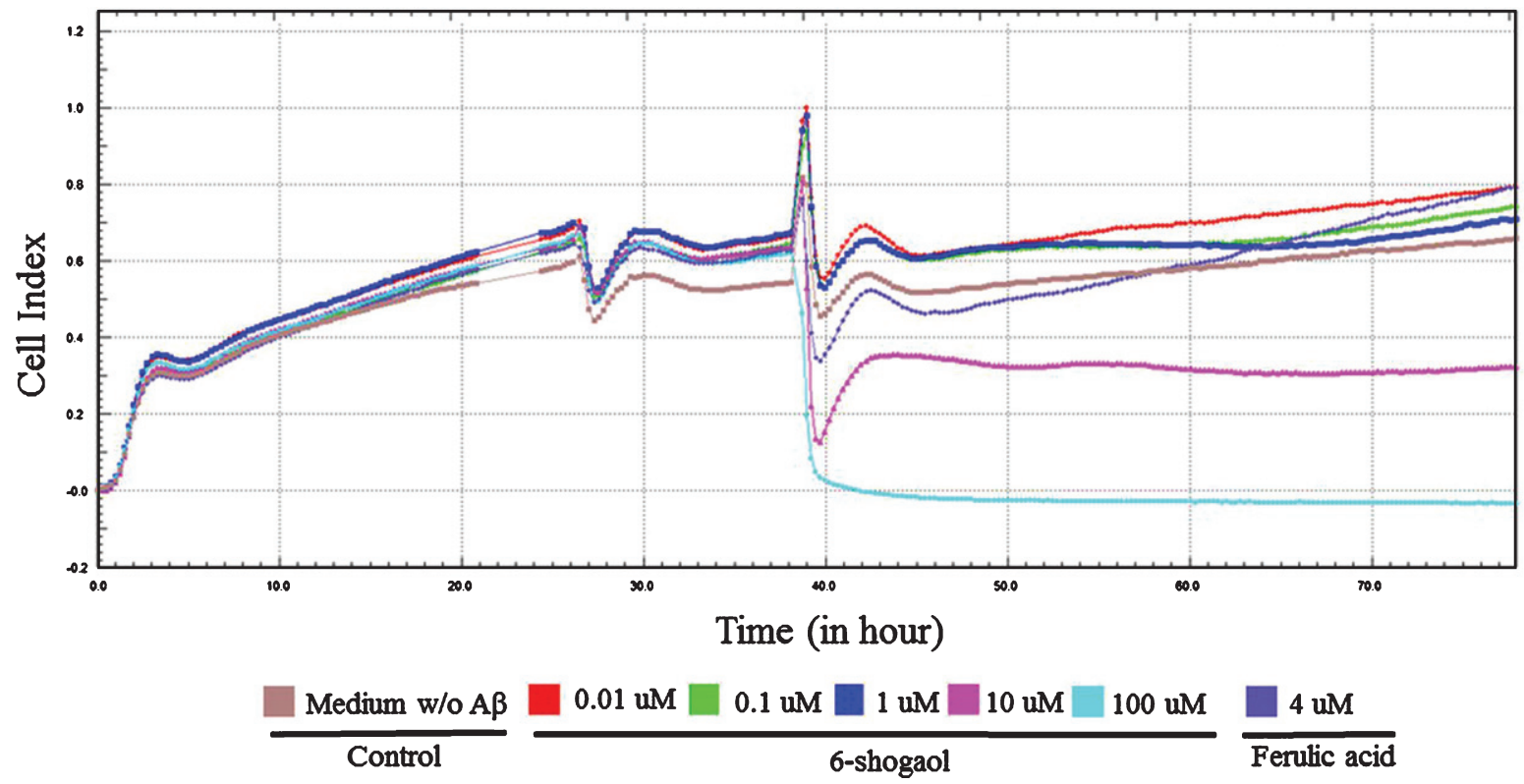

Fig. 2. The effect of 6-shogaol at $0.01 \mu \mathrm{M}, 0.1 \mu \mathrm{M}, 1 \mu \mathrm{M}, 10 \mu \mathrm{M}, 100 \mu \mathrm{M}$ doses $/ 50 \mu \mathrm{L}$ and ferulic acid.

\subsection{The realtime effects of 6-gingerol, 6-shogaol and ferulic acid on cell proliferation with amyloid beta aggregate toxicity}

Amyloid beta 1-42 aggregate decreased the cell indexes and showed antiproliferative effect on the SHSY-5Y cells. Ferulic acid has triggered the cell proliferation after around 24 hours whereas 6-gingerol was not able to recover the cells as ferulic acid did (Fig. 3).

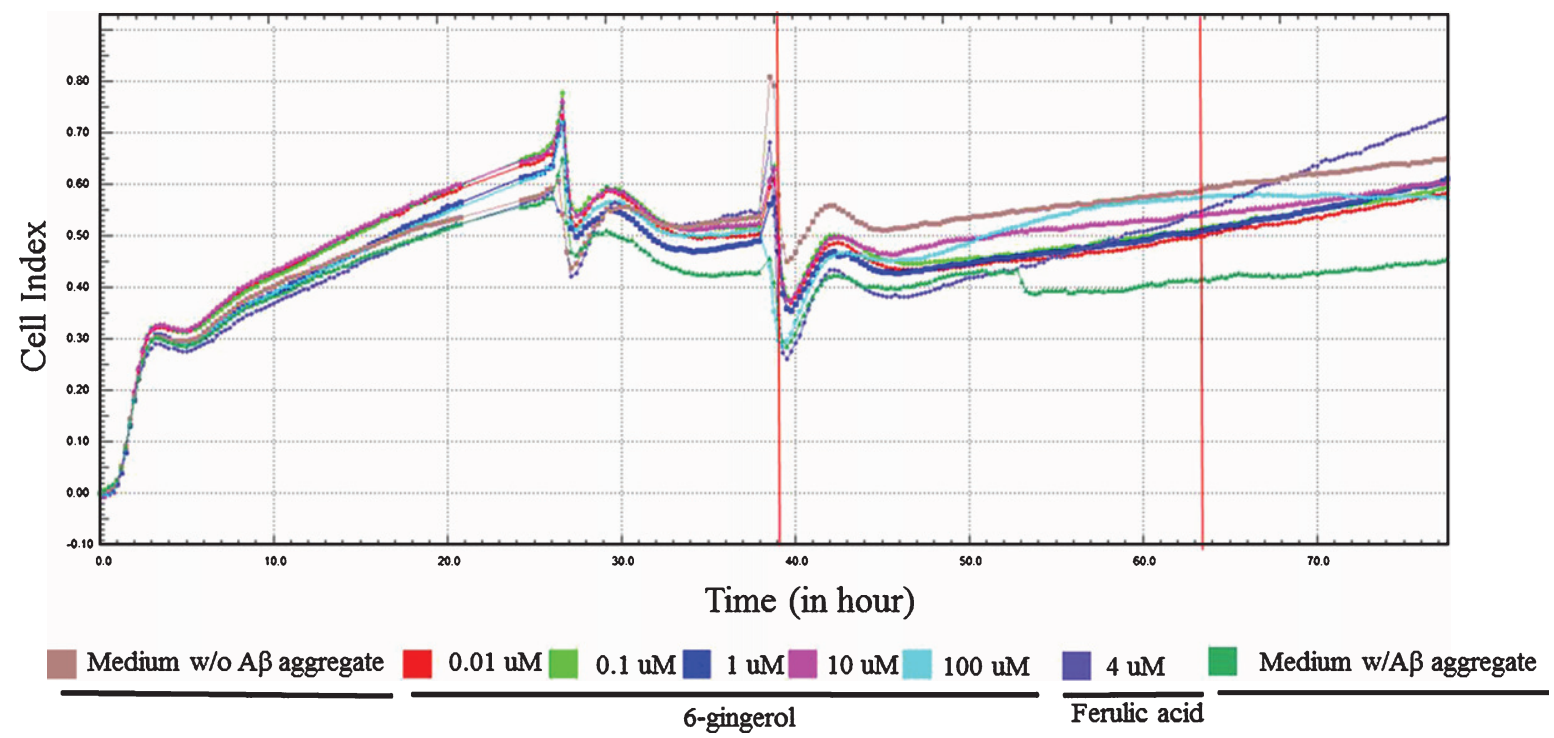

Fig. 3. The effect of gingerol at $0.01 \mu \mathrm{M}, 0.1 \mu \mathrm{M}, 1 \mu \mathrm{M}, 10 \mu \mathrm{M}, 100 \mu \mathrm{M}$ doses $/ 50 \mu \mathrm{L}$ and ferulic acid after amyloid beta $1-42$ aggregate toxicity. 


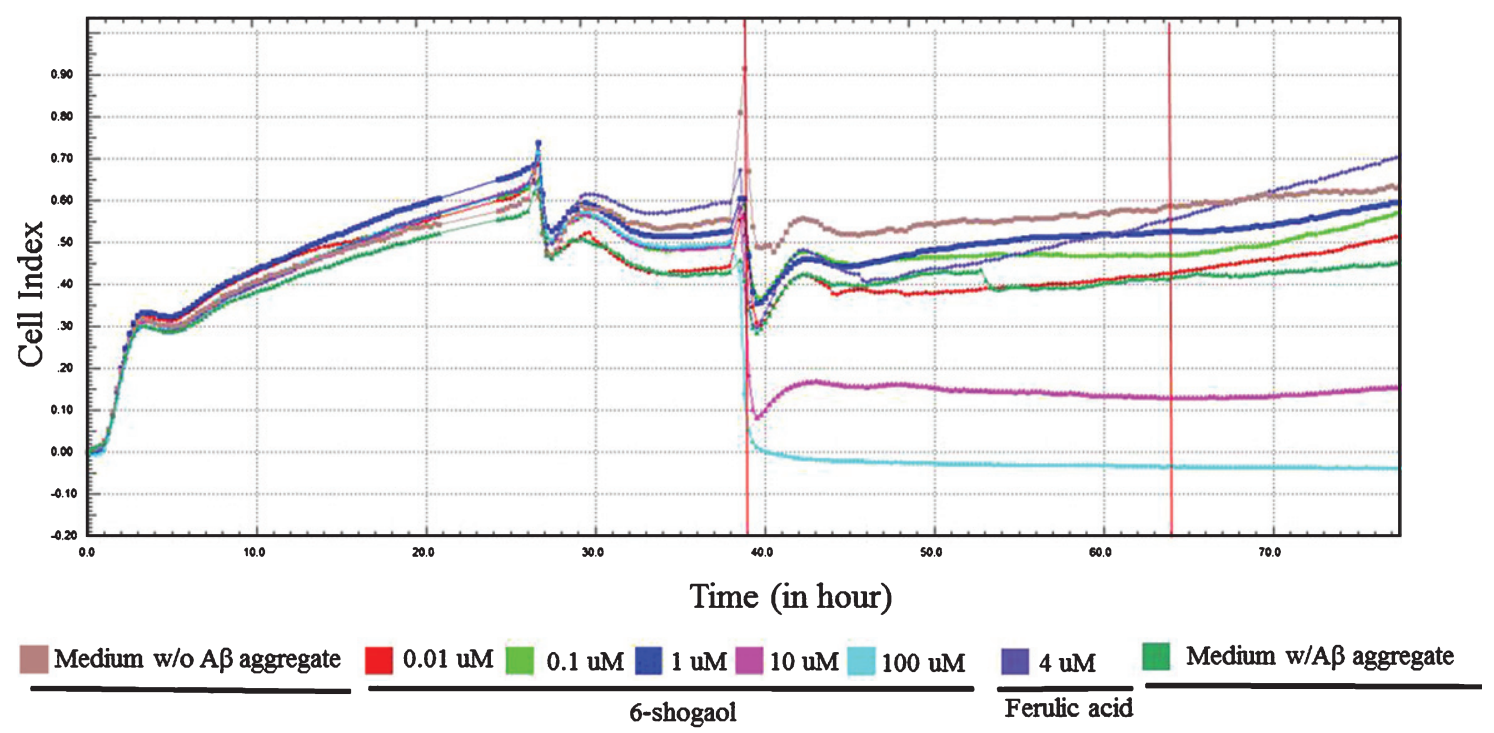

Fig. 4. The effect of 6-shogaol at $0.01 \mu \mathrm{M}, 0.1 \mu \mathrm{M}, 1 \mu \mathrm{M}, 10 \mu \mathrm{M}, 100 \mu \mathrm{M}$ doses $/ 50 \mu \mathrm{L}$ and ferulic acid after amyloid beta $1-42$ aggregate toxicity.

Ferulic acid has triggered the cell proliferation after around 24 hours whereas 6-shogaol was not able to recover the cells as ferulic acid did. Furthermore 6-shogaol itself revealed a cytotoxic effect again at $10 \mu \mathrm{M}, 100 \mu \mathrm{M}$ doses (Fig. 4).

\subsection{The realtime effects of 6-gingerol, 6-shogaol and ferulic acid on cell proliferation with amyloid beta oligomer toxicity}

The amyloid beta oligomer has decreased the cell indexes of the cell lines revealing a direct toxicity to the cell line, 6-gingerol has recoverd the cells as a dose dependent manner, and after around

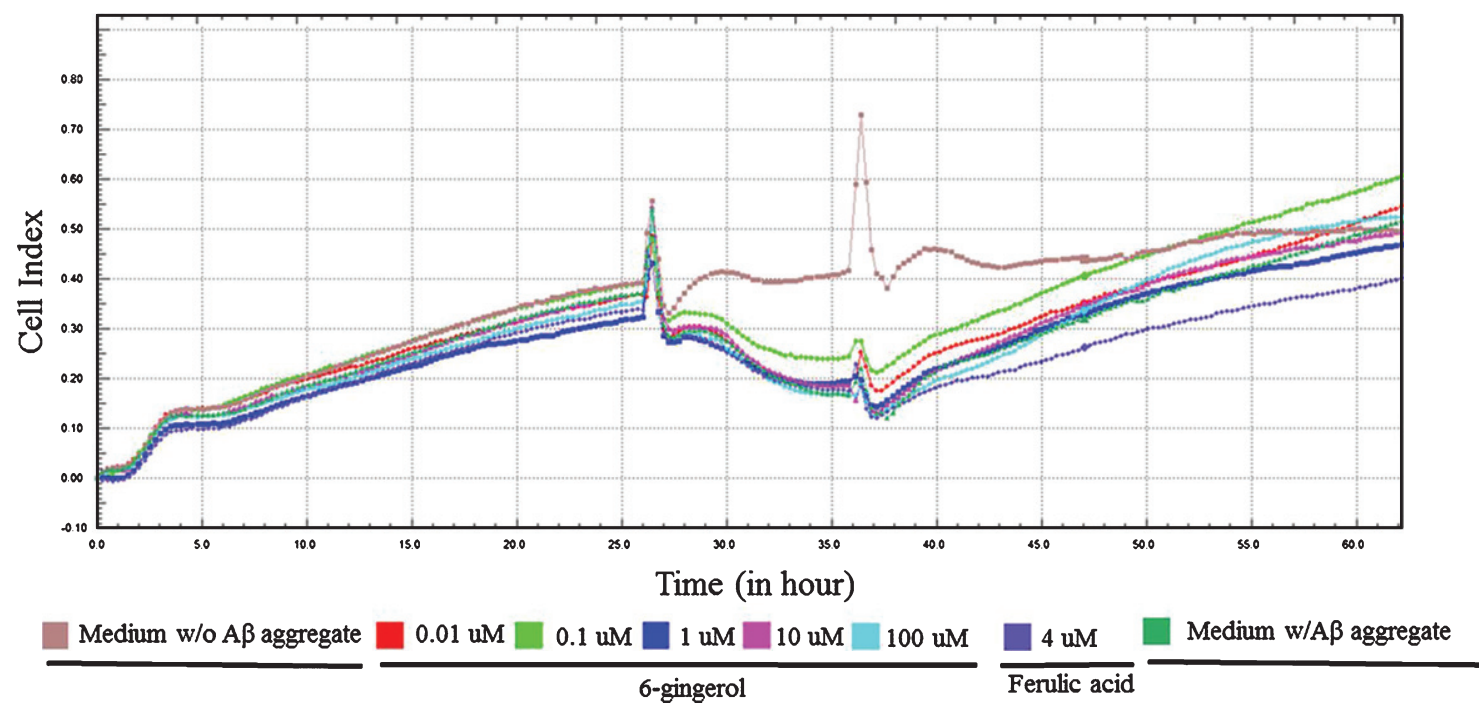

Fig. 5. The effect of 6-gingerol at $0.01 \mu \mathrm{M}, 0.1 \mu \mathrm{M}, 1 \mu \mathrm{M}, 10 \mu \mathrm{M}, 100 \mu \mathrm{M}$ doses $/ 50 \mu \mathrm{L}$ and ferulic acid after amyloid beta 1-42 oligomer toxicity. 


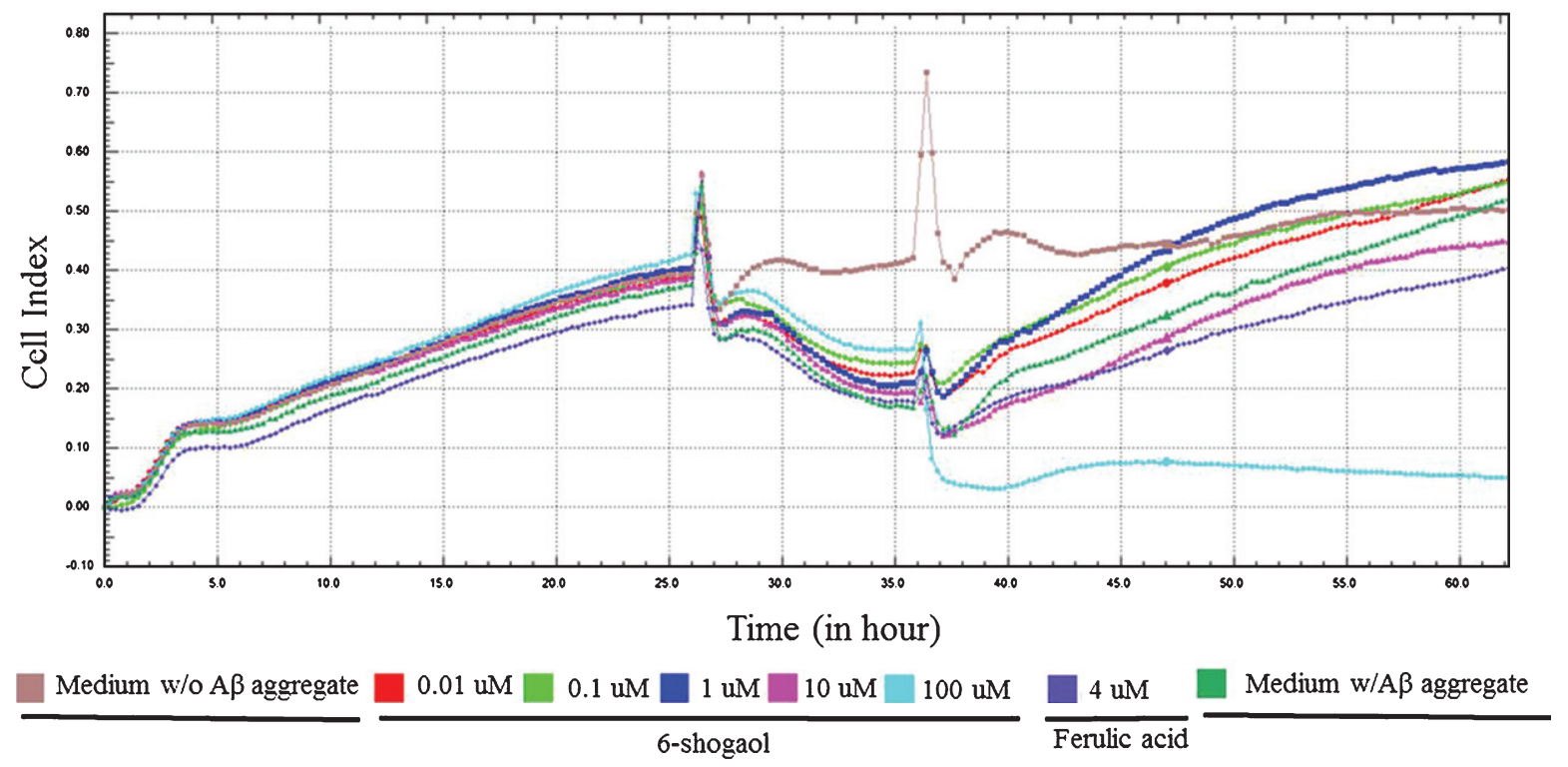

Fig. 6. The effect of 6-shogaol at $0.01 \mu \mathrm{M}, 0.1 \mu \mathrm{M}, 1 \mu \mathrm{M}, 10 \mu \mathrm{M}, 100 \mu \mathrm{M}$ doses $/ 50 \mu \mathrm{L}$ and ferulic acid after amyloid beta $1-42$ oligomer toxicity.

24 hours the effect of gingerol was much more better than the ferulic acid especially at the lower doses (Fig. 5).

6-shogaol could not protect the cells from amyloid beta 1-42 oligomer toxicity, and again up to $1 \mu \mathrm{M}$, it seems to be protective but after $10 \mu \mathrm{M}$ it starts to be toxic to cells decreasing the cell lines (Fig. 6).

\subsection{Dose-response curves and $E C_{50}$ values of the compounds 24 hours after the application}

\subsubsection{Dose-response curve of the 6-gingerol after amyloid beta aggregate toxicity}

The dose-response curve of the 6-gingerol after amyloid beta aggregate toxicity has revealed an EC50 value of $11.2 \mu \mathrm{M}$ (Fig. 7).

Amyloid beta aggregate toxicity have decreased the cell indexes compared to control group significanty, whereas even gingerol at all doses used and ferulic acid recovered this toxicity at around 24 hours (Fig. 8).

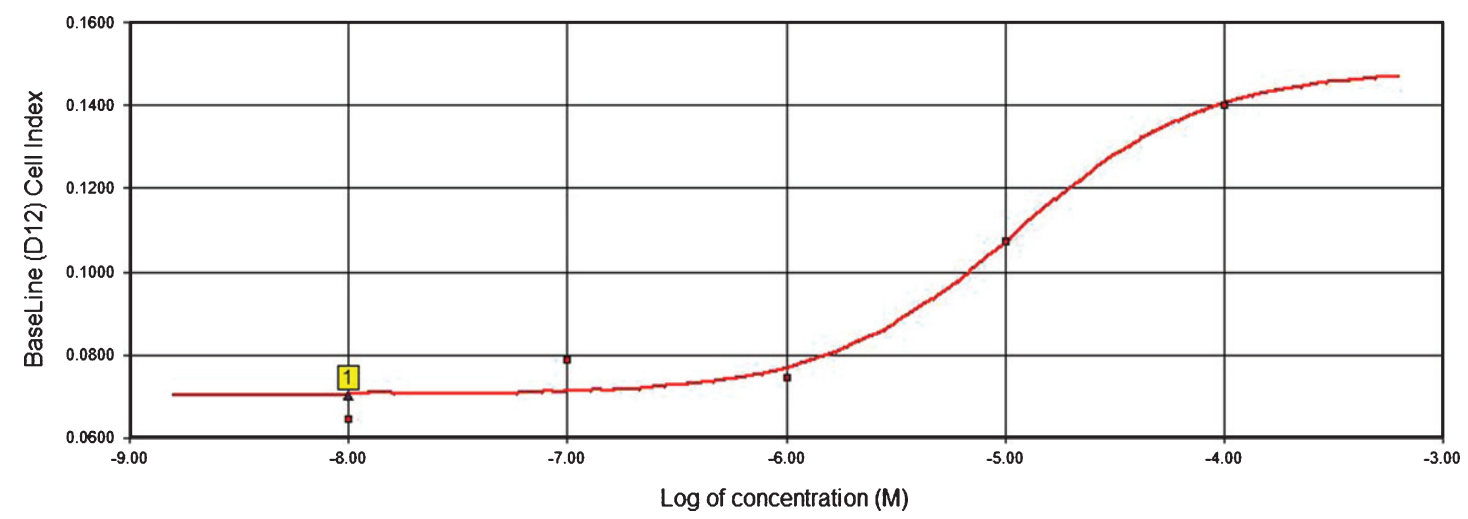

Fig. 7. Dose response curve of 6-gingerol after amyloid beta aggretgate toxicity. 


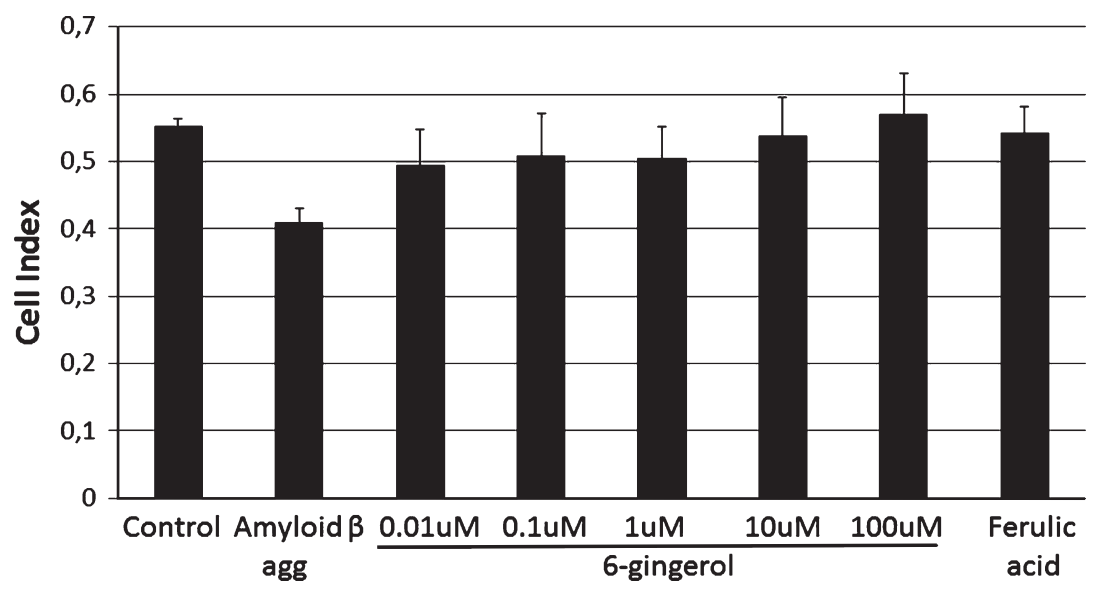

Fig. 8. Cell index alterations after $24 \mathrm{~h}$ from 6-gingerol application.

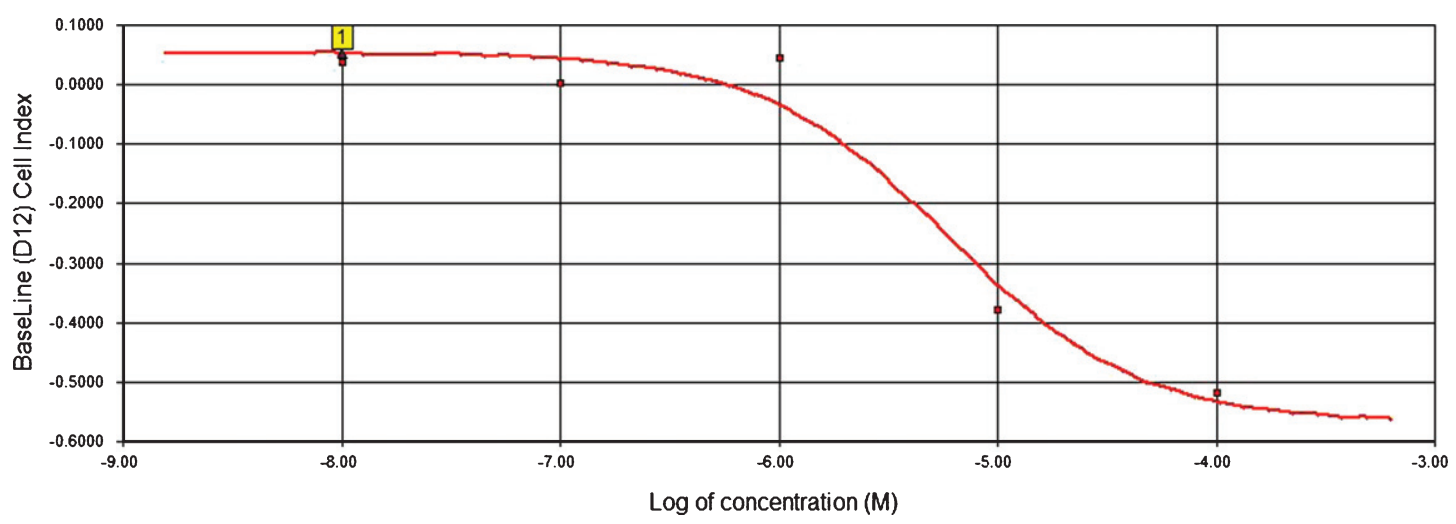

Fig. 9. Dose response curve of 6-shogaol after amyloid beta aggretgate toxicity.

\subsubsection{Dose-response curve of the 6-shogaol after amyloid beta aggregate toxicity}

The dose-response curve of the 6-shogaol after amyloid beta aggregate toxicity has revealed an $\mathrm{IC}_{50}$ value of $6 \mu \mathrm{M}$ (Fig. 9).

Amyloid beta aggregate toxicity have decreased the cell indexes compared to control group significanty. Ferulic acid recoverd this toxicity, where as shogaol at low doses increased the cell index but this increase was not dose dependent and significant (Fig. 10). Furthermore, at higher doses than $10 \mu \mathrm{M}$ shogaol itself had cytotoxic effect rather than being protective at that doses.

\subsubsection{Dose-response curve of the 6-gingerol after amyloid beta oligomer toxicity}

The dose-response curve of the 6-gingerol after amyloid beta oligomer toxicity has revealed an $\mathrm{EC}_{50}$ value of $0.1 \mu \mathrm{M}$ (Fig. 11).

The amyloid beta oligomers shown a cytotoxic effect on SHSY-5Y cells. Ferulic acid was able to recover the cells, from this toxicity, increasing the cell indexes around control levels. However, 6-gingerol was not able to recover the cells significantly and in a dose dependent manner (Fig. 12).

\subsubsection{Dose-response curve of the 6-shogaol after amyloid beta oligomer toxicity}

The dose-response curve of the 6-shogaol after amyloid beta oligomer toxicity has revealed an $\mathrm{IC}_{50}$ value of $34 \mu \mathrm{M}$ (Fig. 13). 


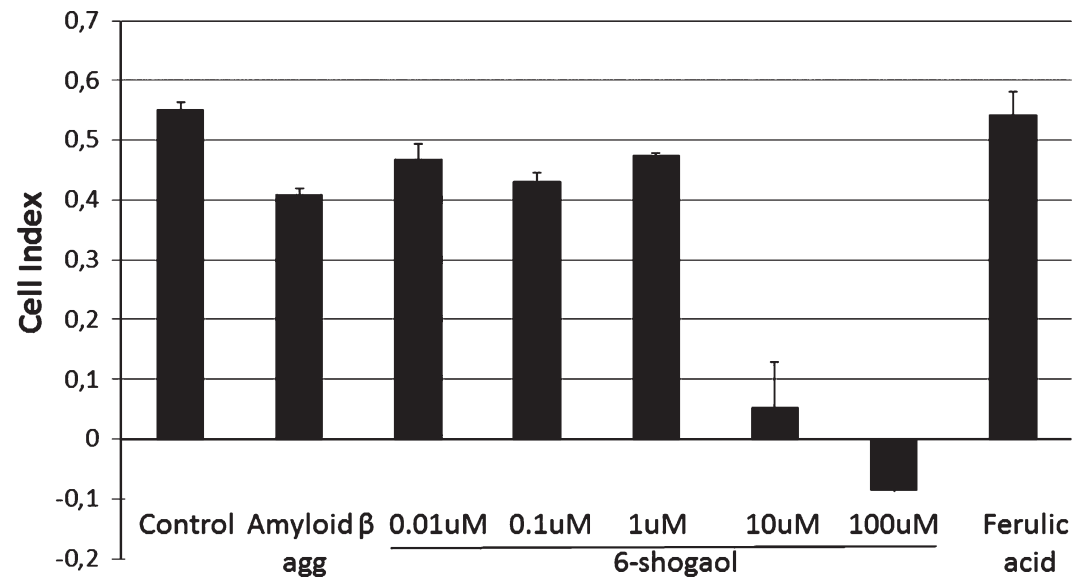

Fig. 10. Cell index alterations after $24 \mathrm{~h}$ from 6-shogaol application.

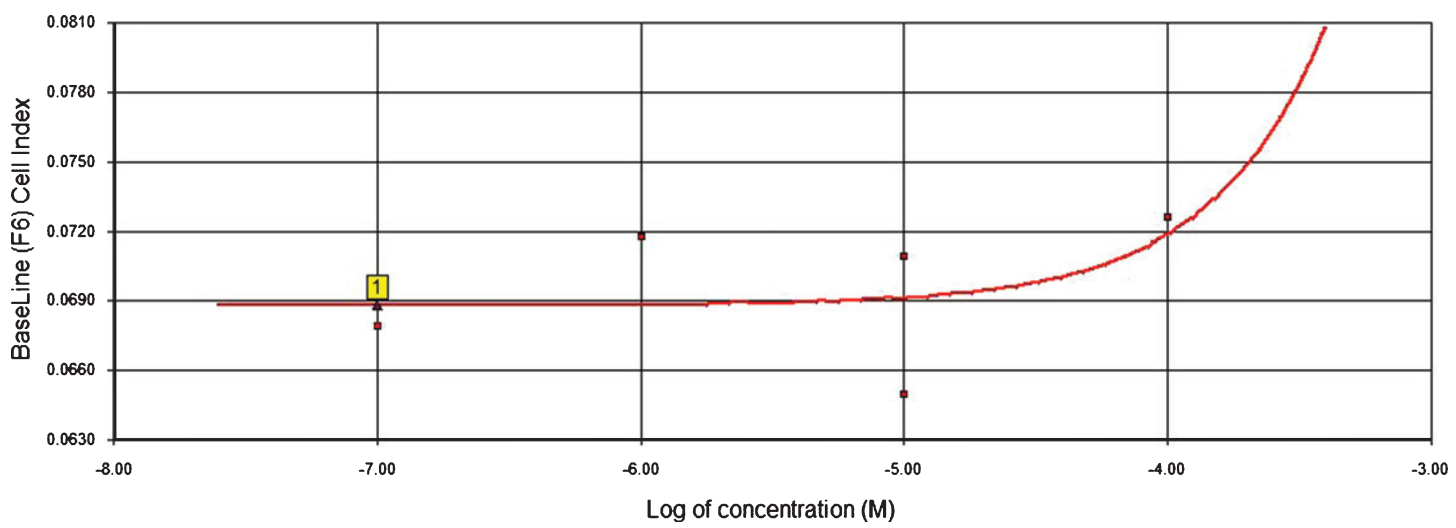

Fig. 11. Dose response curve of 6-gingerol after amyloid beta oligomer toxicity.

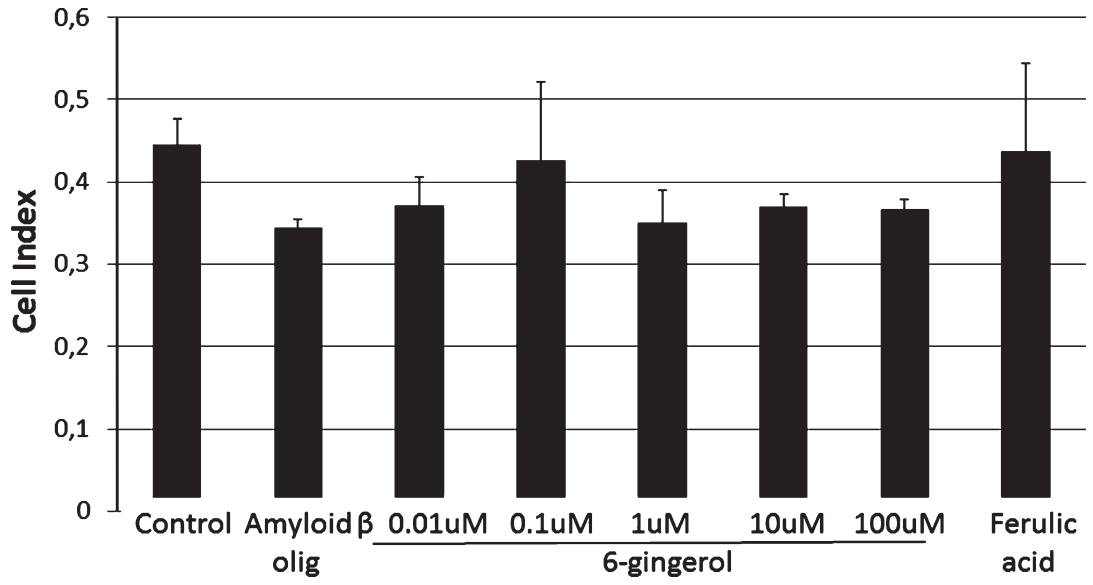

Fig. 12. Cell index alterations after $24 \mathrm{~h}$ from 6-gingerol application. 


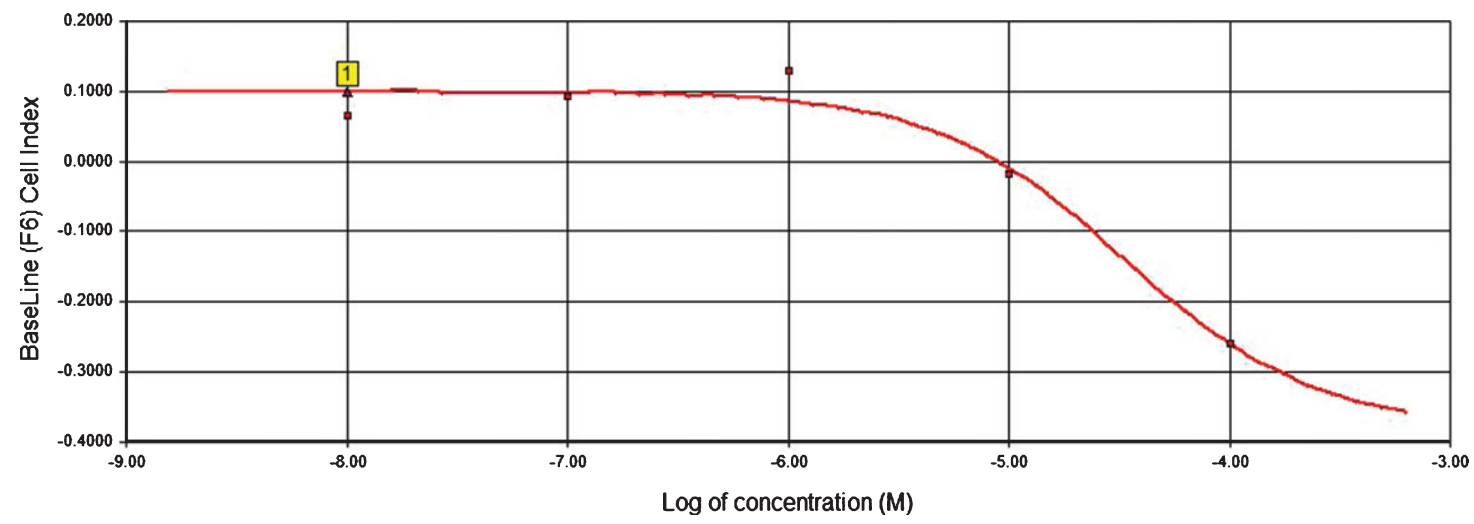

Fig. 13. Dose response curve of 6-shogaol after amyloid beta oligomer toxicity.

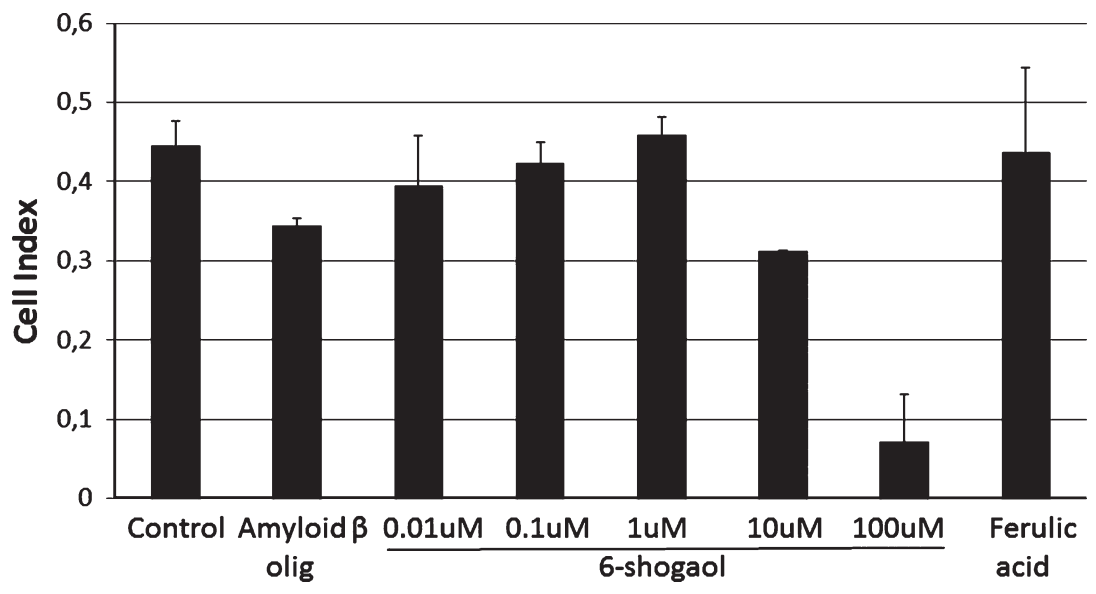

Fig. 14. Cell index alterations after $24 \mathrm{~h}$ from 6-shogaol application.

The amyloid beta oligomers shown a cytotoxic effect on SHSY-5Y cells. As well as the ferulic acid, 6-shogaol at low doses was able to recover the cells, increasing the cell indexes around control levels. However, 6-shogaol again at higher doses over $1 \mu \mathrm{M}$ have caused cytotoxic effects to the cells (Fig. 14).

\subsection{GSK-3 $\beta$ activity results}

GSK-3 $\beta$ activity was calculated as mentioned in the methods part by using the negative and positive control data. As the positive control TDZD-8 was used.

6-gingerol inhibited the GSK-3 $\beta$ enzyme activity at a dose dipendent manner. The inhibitor effect of 6-gingerol after $1 \mu \mathrm{M}$ did not changed revealing the maximum efficacy of 6-gingerol had been reached after this dose (Fig. 15).

The maximum inhibitory effect of 6-shogaol on GSK-3 $\beta$ enzyme was at the dose of $0.1 \mu \mathrm{M}$, but the inhibitory effect of 6-shogaol on the enzyme decreased in a dose-dependent manner. Ferulic acid has $\% 34$ inhibition on GSK-3 $\beta$ activity (Fig. 16). 


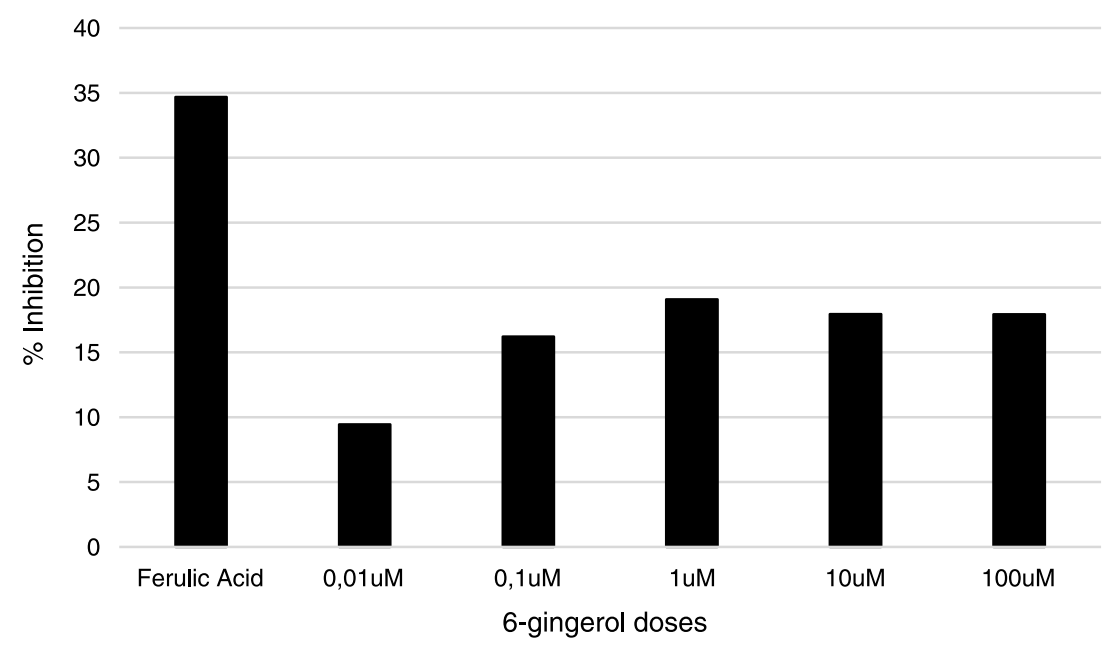

Fig. 15. The inhibitory effect 6-gingerol on GSK-3 $\beta$ enzyme activity.

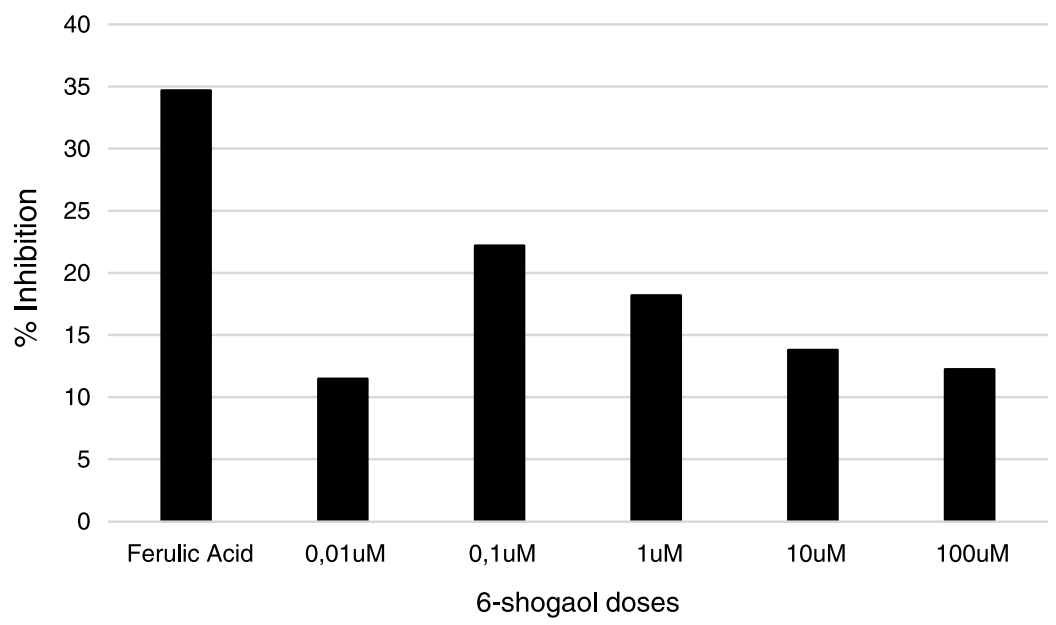

Fig. 16. The inhibitory effect 6-shogaol on GSK-3 $\beta$ enzyme activity.

\section{Discussion}

The amyloid beta $A ß(1-40)$ and $A ß(1-42)$ peptides are the main components of the fibrillar plaques characteristically found in the brains affected by Alzheimer's disease. The Aß peptide is the cleavage product of a precursor membrane protein normally expressed in the organism, known as the Amyloid Precursor Protein (APP). The combined cleavage by the $\beta$ and $\gamma$ secretases of APP results in the production of the amyloid beta fragment that has the capacity to aggregate in the form of the amyloid fibrils further forming the amyloid plaques [22]. GSK-3 $\beta$, has been shown to regulate APP cleavage resulting in the increased production of $A \beta[16,17]$. Exposure of neurones to $A \beta$ increases GSK-3 $\beta$ activity through the inhibition of PI3-kinase signalling and blockadge of either GSK-3 $\beta$ expression or activity prevents $A \beta$-induced neurodegeneration $[18,19]$. In this study, we aimed to determine if 6 -gingerol and 6-shogaol had any protective effect on A $\beta 1-42$-induced cytotoxicity in SHSY-5Y cells via a real time assay and to investigate the underlying mechanisms by which 6-gingerol or 6-shogaol may exert its neuroprotective effects over GSK-3 $\beta$ inhibition. 
The protective effect of 6-gingerol was shown by Lee $C$ and et al., in A $\beta(25-35)$-induced intracellular accumulation of reactive oxygen and/or nitrogen species in SHSY-5Y cells [26]. Zeng GF et al. [27] has revealed that 6-gingerol pretreatment markedly reduced the level of intracellular reactive oxygen species (ROS) and malondialdehyde (MDA), the production of nitric oxide (NO), and the leakage of lactate dehydrogenase (LDH) and increased superoxide dismutase (SOD) activity compared with the A $\beta 1-42$ treatment group. In addition, 6-gingerol pretreatment also significantly enhanced the protein

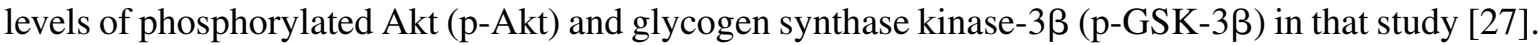
Overall, these results indicate that 6-gingerol exhibited protective effects on apoptosis induced by A $\beta 1-42$ in cultured PC12 cells by reducing oxidative stress and inflammatory responses, suppressing the activation of GSK-3 $\beta$ and enhancing the activation of Akt, thereby exerting neuroprotective effects. Kim DS et al. [28] have isolated four shogaols from the roots of Zingiber officinale that protect IMR32 human neuroblastoma and normal human umbilical vein endothelial cells from beta-amyloid (25-35) insult at $\mathrm{EC}_{50}=4.5-81 \mu \mathrm{M}$. In their further studies, they have synthesized ten shogaols to evaluate the importance of the side-chain length in protecting cells from amyloid betaA(1-42) insult using PC12 rat pheochromocytoma and IMR-32 human neuroblastoma cells [29]. Taking into account this in vitro studies Moon M et al. [30] has shown 6-shogaol was capable to attenuate neuroinflammation and cognitive deficits in animal models of dementia in vivo. In our study, we investigated the neuroprotective effects of these two major components of Zingiber officinale in both amyloid beta (1-42) aggregate and oligomer toxicity in a real time manner for the first time in SHSY-5Y cells. 6-gingerol was able to protect the cells from both aggregate and oligomer toxicity, whereas 6-shogaol was capable to protect the cells in low studies, doses but showed cytotoxic effect at higher doses than $1 \mu \mathrm{M}$. Overall different from all these sudies in our study the neuroprotective effects of both 6-gingerol and 6-shogaol comparing with ferulic acid has been shown in both amyloid beta (1-42) aggregate and oligomer toxicity in a real time manner by using a Real Time Cell Analyzer. This system is capable to show when the effects of the components start and at what time it reaches the highest effect. In our study, it has shown that the protective effects of both 6-gingerol and 6-shogaol might be reached at around 24th hours.

Furthermore in this study, 6-gingerol and 6-shogaol was also evaluated for their effect on GSK-3 $\beta$ activity. 6-gingerol inhibited the GSK-3 $\beta$ activity in a dose dependent manner and its maximum inhibitory effect has been reached at $1 \mu \mathrm{M}$, where it has also shown to protect the cells paralel with this inhibitory effect from both oligomer and aggregate toxicity. The dose-response curve of the 6-gingerol after amyloid beta aggregate toxicity has revealed an $\mathrm{EC}_{50}$ value of $11.2 \mu \mathrm{M}$ and has revealed an $\mathrm{EC}_{50}$ value of $0.1 \mu \mathrm{M}$ after amyloid beta oligomer toxicity. These results also reveal that 6-gingerol is more potent in protecting the cells from oligomer toxicity than the aggregate toxicity. 6-gingerol was protective in all doses used however it was not the case for 6-shogaol. 6-shogaol has protected the cells up to $1 \mu \mathrm{M}$ but it had its own cytotoxicity over $10 \mu \mathrm{M}$ doses. The dose-response curve of the 6-shogaol after amyloid beta aggregate toxicity has revealed an $\mathrm{IC}_{50}$ value of $6 \mu \mathrm{M}$ whereas the $\mathrm{IC}_{50}$ level for oligomer toxicity was $34 \mu \mathrm{M}$. These results might also reveal that 6 -shogaol might trigger the amyloid beta aggregate toxicity but not the oligomer toxicity that much. The GSK-3 $\beta$ inhiibtory effect of 6-shogaol was also parallel with its cytotoxicity results, since at high doses its inhibitory effect on the enzyme decreased. Furthermore, oligomers were more toxic than the aggregates in SHSY-5Y cells and this effect has been also shown for the first time in a real time manner by our study.

In conclusion, 6-gingerol and 6-shogaol both were neuroprotective up to $1 \mu \mathrm{M}$ doses and up to that doses both inhibited the GSK-3 $\beta$ activity, however this inhibitory effect decreased by 6-shogaol over these doses and the cytotoxic effects started which limits the use of 6-shogaol for its protective effect. 6-gingerol seems more potent and safe in all doses used from both amyloid beta (1-42) aggregate and oligomer toxicity. 


\section{References}

[1] Glenner GG, Wong CW. Alzheimer's disease: Initial report of the purification and characterization of a novel cerebrovascular amyloid protein. Biochem Biophys Res Commun 1984;120:885-90.

[2] Hardy JA, Higgins GA. Alzheimer's disease: The amyloid cascade hypothesis. Science 1992;256:184-5.

[3] Pike CJ, Burdick D, Walencewicz AJ, Glabe CG, Cotman CW. Neurodegeneration induced by beta-amyloid peptides in vitro: The role of peptide assembly state. J Neurosci 1993;13(4):1676-87.

[4] Citron M, Oltersdorf T, Haass C, et al. Mutation of the beta-amyloid precursor protein in familial Alzheimer's disease increases beta-protein production. Nature 1992;360:672-4.

[5] Burdick D, Soreghan B, Kwon M, Kosmoski J, Knauer M, Henschen A, Yates J, Cotman C, Glabe C. Assembly and aggregation properties of synthetic Alzheimer's A4/beta amyloid peptide analogs. J Biol Chem 1992;267:546-54.

[6] Howlett DR, Jennings KH, Lee DC, Clark MS, Brown F, Wetzel R, Wood SJ, Camilleri P, Roberts GW. Aggregation state and neurotoxic properties of Alzheimer beta-amyloid peptide. Neurodegeneration 1995;4(1):23-32.

[7] Pike CJ, Walencewicz AJ, Glabe CG, Cotman CW. In vitro aging of $\beta$-amyloid protein causes peptide aggregation and neurotoxicity. Brain Res 1991;563:311-4.

[8] Price JL, Morris JC. Tangles and plaques in nondemented aging and "preclinical” Alzheimer's disease. Ann Neurol 1999;45:358-68.

[9] Goedert M, Spillantini MG. A century of Alzheimer's disease. Science 2006;314:777-81.

[10] Scheuner D, Eckman C, Jensen M, Song X, Citron M, Suzuki N, Bird TD, Hardy J, Hutton M, Kukull W, Larson E, Levy-Lahad E, Viitanen M, Peskind E, Poorkaj P, Schellenberg G, Tanzi R, Wasco W, Lannfelt L, Selkoe D, Younkin $\mathrm{S}$. Secreted amyloid beta-protein similar to that in the senile plaques of Alzheimer's disease is increased in vivo by the presenilin 1 and 2 and APP mutations linked to familial Alzheimer's disease. Nat Med 1996;2(8):864-70.

[11] Deibel MA, Ehmann WD, Markesbery WR. Copper, iron, and zinc imbalances in severely degenerated brain regions in Alzheimer's disease: Possible relation to oxidative stress. J Neurol Sci 1996;143:137-42.

[12] Akiyama H, Barger S, Barnum S, et al. Inflammation and Alzheimer's disease. Neurobiol Aging 2000;21:383-421.

[13] Luchsinger JA, Tang MX, Stern Y, et al. Diabetes mellitus and risk of Alzheimer's disease and dementia with stroke in a multiethnic cohort. Am J Epidemiol 2001;154:635-41.

[14] Boonen RA, van Tijn P, Zivkovic D. Wnt signaling in Alzheimer's disease: Up or down, that is the question. Ageing Res Rev 2009;8:71-82.

[15] Meijer L, Flajolet M, Greengard P. Pharmacologial inhibitors of glycogen synthase kinase 3. Trends in Pharmacological Sciences 2004;25(9):471-80.

[16] Sun X, Sato S, Murayama O, Murayama M, Park JM, Yamaguchi H, Takashima A. Lithium inhibits amyloid secretion in COS7 cells transfected with amyloid precursor protein C100. Neurosci Lett 2002;321(1-2):61-4.

[17] Phiel CJ, Wilson CA, Lee VM, Klein PS. GSK-3alpha regulates production of Alzheimer's disease amyloid-beta peptides. Nature 2003;423(6938):435-9.

[18] Takashima A, Noguchi K, Sato K, Hoshino T, Imahori K. Tau protein kinase I is essential for amyloid beta-proteininduced neurotoxicity. Proc Natl Acad Sci U S A 1993;90(16):7789-93.

[19] Alvarez G, Muñoz-Montaño JR, Satrústegui J, Avila J, Bogónez E, Díaz-Nido J. Lithium protects cultured neurons against beta-amyloid-induced neurodegeneration. FEBS Lett 1999;453(3):260-4.

[20] Koh S, Noh MY, Kim SH. Amyloid beta induced neuritoxicity is reduced by inhibition of glycogen synthase kinase-3. Brain Research 2008;1188;254-62.

[21] Demirpolat E, Yerer MB. Revealing the effect of 6-gingerol, 6-shogaol and curcumin on mPGES-1, GSK-3 $\beta$ and $\beta$-catenin pathway in A549 cell line. Chem Biol Interact 2016;258:257-65.

[22] Benseny-Cases N, Klementieva O, Cladera J. In vitro oligomerization and fibrillogenesis of amyloid-beta peptides. Subcell Biochem 2012;65:53-74.

[23] Fezoui Y, Hartley DM, Harper JD, Khurana R, Walsh DM, Condron MM, Selkoe DJ, Lansbury PT Jr, Fink AL, Teplow DB. An improved method of preparing the amyloid beta-protein for fibrillogenesis and neurotoxicity experiments. Amyloid 2000;7(3):166-78.

[24] Stine WB Jr, Dahlgren KN, Krafft GA, LaDu MJ. In vitro characterization of conditions for amyloid-beta peptide oligomerization and fibrillogenesis. J Biol Chem 2003;278(13):11612-22.

[25] Baki A, Bielik A, Molnár L, Szendrei G, Keserü GM. A High Throughput Luminescent Assay for Glycogen Synthase Kinase-3 $\beta$ Inhibitors. Assay and Drug Development Technologies 2007;5(1):75-84.

[26] Lee C, Park GH, Kim CY, Jang JH. [6]-Gingerol attenuates $\beta$-amyloid-induced oxidative cell death via fortifying cellular antioxidant defense system. Food Chem Toxicol 2011;49(6):1261-9.

[27] Zeng GF, Zong SH, Zhang ZY, Fu SW, Li KK, Fang Y, Lu L, Xiao DQ. The role of 6-gingerol on inhibiting amyloid $\beta$ protein-induced apoptosis in PC12 cells. Rejuvenation Res 2015;18(5):413-21. 
[28] Kim DS, Kim DS, Oppel MN. Shogaols from Zingiber officinale protect IMR32 human neuroblastoma and normal human umbilical vein endothelial cells from beta-amyloid(25-35) insult. Planta Med 2002;68(4):375-6.

[29] Kim DS, Kim JY. Side-chain length is important for shogaols in protecting neuronal cells from beta-amyloid insult. Bioorg Med Chem Lett 2004;14(5):1287-9.

[30] Moon M, Kim HG, Choi JG, Oh H, Lee PK, Ha SK, Kim SY, Park Y, Huh Y, Oh MS. 6-Shogaol, an active constituent of ginger, attenuates neuroinflammation and cognitive deficits in animal models of dementia. Biochem Biophys Res Commun 2014;449(1):8-13. 